\title{
Correction to: Practices of remembering a movement in the dance studio: evidence for (a radicalized version of) the REC framework in the domain of memory
}

\section{Carla Carmona ${ }^{1}$}

Published online: 6 January 2021

(c) Springer Nature B.V. 2021

\section{Correction to: Synthese https://doi.org/10.1007/s11229-020-02949-w}

The original article has been corrected. A typo in the author name A. Peeters in the following reference has been corrected:

Hutto, D., \& Peeters, A. (2018). The Roots of remembering: Radically enactive recollecting. In K. Michaelian, D. Debus, \& D. Perrin (Eds.), New directions in the philosophy of memory (pp. 97-118). New York: Routledge.

Publisher's Note Springer Nature remains neutral with regard to jurisdictional claims in published maps and institutional affiliations.

The original article can be found online at https://doi.org/10.1007/s11229-020-02949-w.

Carla Carmona

ccarmona@us.es

1 Faculty of Philosophy, University of Seville, Seville, Spain 